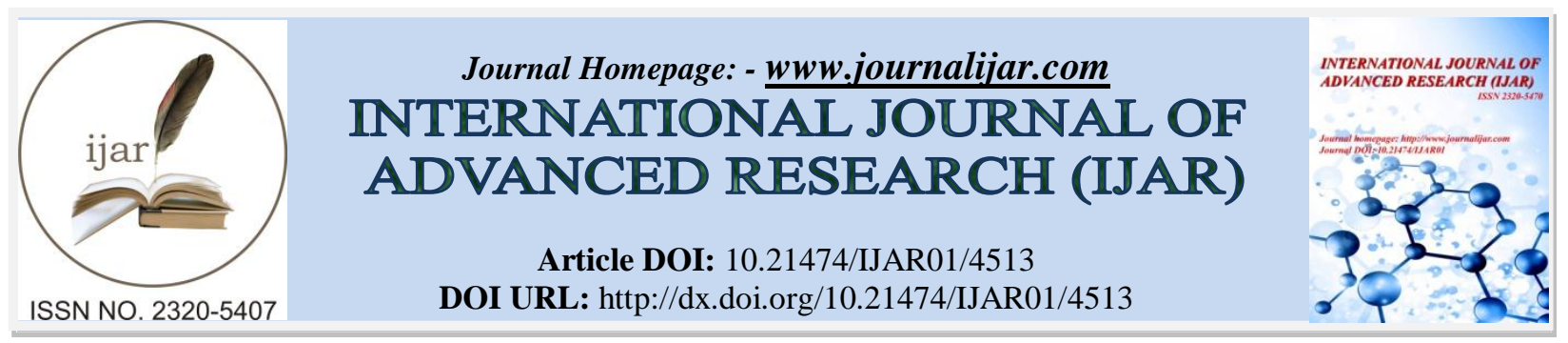

RESEARCH ARTICLE

\title{
PROHIBITION OF COW SLAUGHTER IN INDIA AND PERSONAL LIBERTY OF RIGHT TO EAT.
}

Dr. Dharmendra Kumar Singh.

Associate Professor, Department of Law, Bareilly College, Bareilly.

\section{Manuscript Info}

Manuscript History

Received: 17 April 2017

Final Accepted: 19 May 2017

Published: June 2017

Key words:-

Cow slaughter, Constitution of India,

Personal Liberty, Supreme Court

\section{Abstract}

Enforcement of Article 48 of the Constitution of India related to cow slaughter in its real sense has been the long waited gap and the study will concentrate on providing adequate and positive analysis of existing Law. Cow-question now a day is a very sensitive issue in Indian society. If this is not tackled in a responsible way, the harmony of the society will suffer seriously. This paper describes the Constitutional, Judicial, and Legislative framework of cow slaughtering in India and proposes the significance of balance between the eating habits of people of different States and cow slaughter in India. A proper analysis and perfect formulation of the problem will pave a reliable way to avoid unnecessary societal tension by the way of suggesting a proper measure to deal with the problem. This paper puts forth the need of a constitutional amendment so that a central law is made for the whole nation.

Copy Right, IJAR, 2017,. All rights reserved.

\section{Introduction:-}

Law has a major role in guiding and shaping the social occurrences to alter the menaces in the society. The relationship of law and the society is established in many ways. Law, also called as social engineering is not only a trusted means of social change and control but a tool used for promoting, maintaining and taking forward the human civilization in an efficient manner. Law is social engineering and it is the part of an engineer to adjust many difficulties and provide a viable and workable structure. This is vital for the existence and survival of any society to provide and maintain a framework to hold the very responsibility. That is why academia looks very fondly towards the law if they find any problem threatening the peace and prosperity of the society. It has become more relevant after evolution of modern state and law has become a distinguished moderator in the society as well as an effective mean of social control.

The cow is the foundation of Indian economy, one of the greatest economies in the world. It is forgotten that the Hindu Religion, the Hindu Culture and the Indian life are woven around the cow, and in consequence protagonists of cow-slaughter ban are dubbed religious fanatics, communalists and reactionaries by the foreign and the Indian vested interests whose vigorous propaganda has created an atmosphere of skepticism in the country, clouding the real issue. A proportionally large section of people of India lives rural life and practices agriculture as the most dominant occupation.

Livestock sector plays a critical role in the welfare of India's rural population. It contributes nine percent to Gross Domestic Product and employs eight percent of the labor force. This sector is emerging as an important growth leverage of the Indian economy with India being the largest producer of milk as18.5\% word production in 2015-16. Livestock production and agriculture are intrinsically linked, each being dependent on the other, and both crucial for 
overall food security. Livestock sector is an important subsector of the agriculture of Indian economy. It forms an important livelihood activity for most of the farmers; supporting agriculture in the form of various by-products. India has vast resource of livestock and poultry, which pay a vital role in improving the socio-economic conditions of rural masses [2] (GOI, 2014).

\section{Analysis of Constitutional and legislative Provision on Cow Slaughter:- Constitutional Provision:-}

The Constitution of India is a specific legal instrumental document of Polity and it is meant to reflect the nation's expectations too. Directive Principles of State Policy (DPSP) enshrined in Indian Constitution has a pioneering position in the provisions intended to frame the social, economical and political structure of the prospective India. The primordial importance of these principles can be understood by the following words of Dr. B.R Ambedkar [3], when he insisted on the use of the word "strive" in the language of Article 38 which mentions the governmental objective of an equitable distribution of material resources:

"We have used it because it is our intention that even when there are circumstances which prevent the Government, or which stand in the way of the Government giving effect to these directive principles, they shall, even under hard and unpropitious circumstances, always strives in the fulfillment of these directives. ... Otherwise it would be open for any Government to say that the circumstances are so bad, that the finances are so inadequate that we cannot even make an effort in the direction in which the Constitution asks us to go."

Here, it is noteworthy that these provisions in Part IV are left to enforce as per the intent and ease of the respective governments. Article 48 [4] of the Constitution as one of the Directive Principles of State Policy listed in Part IV. It says so:

"The state shall endeavour to organise agriculture and animal husbandry on modern and scientific lines and shall, in particular, take steps for preserving and improving the breeds, and prohibiting the slaughter, of cows and calves and other milch and draught cattle."

The word "endeavour" is used in several other Directive Principles of State Policy (Articles 43, 44, 45, 47, 48A and 51); "strive" is used in Article 38(1) and (2); "shall take steps" in Articles 40, 43A and 50. "Shall take steps" is a stronger word for prohibition than "endeavour". Capping all of them is Article 37 [5], which says:

"The provisions contained in this Part shall not be enforceable by any court, but the principles therein laid down are nevertheless fundamental in the governance of the country and it shall be the duty of the state to apply these principles in making laws."

Enforcement of the mandate given in Article 48 has been a need for a long time. The nature of these guidelines is made clear. It proposes vast welfare of the Indian society and provides mantra of comprehensive development of the Nation and thus proves its vital importance [6]. In spite of it the prominence of enforcement question could not fade its relevance ever after passing approximately seven decades. It is also to be taken in notice that some consideration has been devoted prior to this area.

Cows and its progeny make a crucial fraction of economy and attain a glorious reputation in major fraction of the Indian society. The Constitution pronounces a clear mandate in the favour of protection of the sacred and worthy animal. What is done in accordance of the mandate is enactment of legislative pieces in various states of the India. Banning the slaughter partially and completely has been the mere directions in those wordy pieces otherwise the incidences relating to slaughter of cow and related criminal incidences may not be so common here. Validity of such legislations was challenged in courts. In Laxmi Khandsari v. State of Uttar Pradesh [7] the Supreme Court has asserted that an important consideration which must weigh with the courts in determining the reasonableness of a restriction is that it should not contravene the directive principles. The Directive Principles aim at establishing an egalitarian society so as to bring about a welfare state and these principles should be kept in mind in judging the question as to whether or not the restrictions are reasonable vis-à-vis Art 19(6).

Prohibition of slaughter of cows, bulls and bullocks to enable the public to have a sufficient supply of milk, and to ensure availability of sufficient number of draught cattle for agricultural operations was held reasonable under Art 19(6) in view of the directive principle contained in Arts 47 and 48. 


\section{Legislative Provision on Cow Slaughter:-}

Cow slaughter legislation comes under purview of States as the power to regulate the matter related to it are subjects of 'State' List'. In pursuance of the directive principle of state policy, as contained in Article 48 of the Constitution of India, most States have enacted laws in one form or the other, relating to the prohibition on slaughter of the cow and its progeny.

The Assam Cattle Preservation Act was the first State law that came in 1950 and the following legislations were brought into the statute books in different States.

1. The Bombay Animal Preservation Act, 1954

2. The Bihar Preservation and Improvement of Animals Act, 1955

3. The Punjab Prohibition of Cow Slaughter Act, 195

4. The Himachal Pradesh Prohibition of Cow Slaughter Act, 1955

5. The Uttar Pradesh Prohibition of Cow Slaughter Act, 1955

6. The Tamil Nadu Animal Preservation Act, 1958

7. The Madhya Pradesh Agricultural Cattle Preservation Act, 1959

8. The Orissa Prevention of Cow slaughter Act, 1960

9. The Pondichery Prevention of Cow Slaughter Act, 1968

10. The Karnataka Prevention of Cow Slaughter and Cattle Preservation Act, 1964

11. The Maharashtra Animal Preservation Act, 1976

12. The Andhra Pradesh Prohibition of Cow Slaughter and Animals Preservation Act, 1977

13. The Goa Daman \& Diu Prevention of Cow Slaughter Act, 1978 and The Goa Animal Preservation Act, 1995)

14. The Delhi Agricultural Cattle Preservation Act, 1994

15. The Rajasthan Bovine Animal (Prohibition of Slaughter and Regulation of Temporarily Migration of Export) Act, 1995.

It will be seen that, in some States there are exclusive cattle preservation laws, whereas in other States, Animal preservation laws have been enacted, extending protection to other animals also, including those belonging to the bovine species. Also, some States have specific Acts for prohibition of slaughter of cows, whereas others relate to preservation of agricultural cattle. In respect of the newly-created States of Jharkhand, Telangana, Uttaranchal and Chattisgarh, the laws of undivided Bihar, Andra Pradesh, Uttar Pradesh and Madhya Pradesh prevail, as the new States are yet to formulate their own laws. Kerala is the only major State, apart from some of the North Eastern States, which does not have an Act with regard to slaughter of cattle.

Lack of uniformity in existing legislations on Cow Slaughter:-

It will be seen that there is a complete lack of uniformity in these State laws. By and large, most of the laws prohibit the slaughter of cows of all ages. However, Assam, Tamil Nadu and West Bengal permit the slaughter of even cows of over 14, 10 and 14 years of age, respectively. Most States prohibit the slaughter of calves, whether male or female. However, except for Bihar and Rajasthan, where age of a calf is given as below 3 years, the other Acts have not defined the age of a calf. In Maharashtra, the Commission was told that the definition of calf being followed, by some executive instructions, was 'below the age of 1 year'.

Delhi, Gujarat, Madhya Pradesh, Punjab and Rajasthan have banned totally the slaughter of cow and its progeny, including bulls and bullocks of all ages. The Uttar Pradesh Act permits the slaughter of bulls and bullocks of over 15 years or who have become permanently incapacitated. However, by an Ordinance issued in 2001, the Uttar Pradesh Government prohibited the slaughter of cow and its progeny.

Most of the legislations specify that offences would be cognisable. However, only Delhi, Goa, Pondicherry, Punjab and Uttar Pradesh have made the offences both cognisable and non-bailable. The maximum term of imprisonment varies from 6 months to 5 years (Delhi and Haryana) and the fine from Rs.1,000 to Rs.10,000. Delhi and Madhya Pradesh have fixed minimum term of imprisonment at 6 months. So, the provisions vary State to State not only in definitions and its attitude but the punishment and penalties imposed for the fault too.

One of the biggest challenges in the implementation of the aforesaid laws is the perilous acts of different lawbreakers, namely Cattle mafias, leather industries, cattle smugglers etc. In reference to newspaper reports, it is often observed that, due to cow-slaughter provisions, the birth of 'Inspector- Raj has taken place and the police assist these lawbreakers in many states. 
Cattle commission recommendation on Amendment in the Constitution of India:-

National Commission on Cattle in its 2002 report [8] suggested that there are two ways in which Parliament can legislate on the subject. The simple process would be to bring about an amendment of the Constitution and shift entry 15 (relating to preservation, protection and improvement of stock and prevention of animal diseases) of List II of the Seventh Schedule of the Constitution to List III of the same Schedule, which is the Concurrent List or the list of subjects on which both the Centre and the States are competent to legislate. There have been several such amendments. For example, Education was an item on List II and by the 42nd Amendment in 1976 was shifted to the Concurrent List as item No. 25 of List III.

National Commission on Cattle recommended that this would require an amendment within Article 368 of the Constitution.

1. The Commission, therefore, recommends that early steps may be taken for a Parliamentary Legislation applicable to the whole country by repealing various legislations now in force.

2. Preservation, protection and improvement of stock and prevention of animal diseases is presently an item at Entry No. 15 of List II (State List) of the Constitution's Schedule VII. Unless, by an appropriate amendment, the entry for this head of Legislation is taken from List II and put in List III (Concurrent List), Parliament would not have the legislative competence to bring forth a Central Legislation on the subject.

3. The Commission is of the view that Entry 15 of List II should be shifted to List III to enable Parliament to give proper attention to the matter and bring about proper legislation. The Central Government never paid any heed to this recommendation and after 14 years of the recommendation, lack of uniformity and implementation of the State law is still the biggest problem. The Supreme Court in State of Gujarat vs Mirzapur Moti Kureshi Kaseab Jamat [9] seven judges' bench (by the majority of 6:1) accepted some recommendations of National Commission on Cattle (2002) in its pronouncement.

\section{Judicial Analysis of Prohibition of Cow Slaughter and Personal Liberty of Right to Eat:- Prohibition on Cow Slaughter:-}

A Constitution Bench of the Supreme Court in the Hanif Quareshi Vs. State of Bihar known as 'Quareshi-I' case [10] was examining the validity of the provisions of the Bihar Preservation and Improvement of Animals Act, the U.P. Prevention of Cow Slaughter Act and the C.P. and Berar Animal Preservation Act, has held that butchery is a profession and citizens have a fundamental right under Article 19 (1) (g) to carry on the same, subject to sub-article 19 (6). The Constitution Bench of the Supreme Court, on examining the legal position, has come to the conclusion that:

1. A total ban on the slaughter of the cow of all ages and calves of cows and of the buffaloes, male and female was quite reasonable and valid;

2. A total ban on the slaughter of she buffaloes or breeding bulls or working bullocks (cattle as well as buffalo) as long as they were capable of being used as milk or draught cattle, is also reasonable and valid;

3. A total ban on the slaughter of she buffaloes, bulls and bullocks (cattle and buffaloes) after they ceased to be capable of yielding milk or of breeding or working as draught animals, was not in the interest of general public and was invalid.

4. The Supreme Court came to the conclusion that sacrifice of a cow on the occasion of the Id Kurbaani is not a religious mandate. The slaughter of the animals has, therefore, no religious sanction and the issue has to be considered on its own perspective.

\section{Speaking for the court, Chief Justice S.R. Das observed [11]:-}

"There can be no gainsaying the fact that the Hindus in general hold the cow in great reverence and the idea of the slaughter of cows for food is repugnant to their notions and this sentiment has in the past even led to communal riots. It is also a fact that after the recent partition of the country this agitation against the slaughter of cows has been further intensified. While we agree that the constitutional question before us cannot be decided on grounds of mere sentiment, however passionate it may be, we, nevertheless, think that it has to be taken into consideration, though only as one of many elements, in arriving at a judicial verdict as to the reasonableness of the restrictions."

\section{Chief Justice Das also noted [12]:-}

"There is also no getting away from the fact that beef or buffalo meat is an item of food for a large section of the people in India and in particular of the State of Bihar and Uttar Pradesh."Justice J.C. Shah totally disagreed with the majority view delivered by Chief Justice S.R.Das. 
The decision was followed by legislative amendments designed to prevent the slaughter of cattle after they ceased to be capable of yielding milk or of breeding or of working as draught animals. In 1961 Abdul Hakim Quraishi vs State of Bihar [13] these amendments were again challenged as violating Article 19(1) (g). In addition to urging some of the grounds which had been held to justify the slaughter of old and unfit cattle, the petitioners contended that as a result of the raising of the age limit there would be no bullocks or buffaloes or she-buffaloes available for slaughter as few of the animals survived in India up to the age of 15 years and that millions of members of the minority community would be deprived of cattle-beef which was a staple item of their diet. Affidavits on behalf of the States tried to justify the raising of the limit from 15 to 20 years or 25 years. This decision is famous in the legal circle as 'Quereshi II'.

\section{On careful consideration of the evidence, the Supreme Court held that [14]:=-}

"...the almost unanimous opinion of experts is that after the age of 15, bulls, bullocks and buffaloes are no longer useful for breeding, draught and other purposes and whatever little use they may have then is greatly offset by the economic disadvantages of feeding and maintaining unserviceable cattle-disadvantages to which we had referred in much greater detail in Mohd. Hanif Quareshi's case (1959) SCR 629."

The notification impugned in another case, Mohammed Faros vs MP [15] was described in allowing the petition, Justice Shah speaking for a constitution bench of five judges, said:

"The sentiments of a section of the people may be hurt by permitting slaughter of bulls and bullocks in premises maintained by a local authority. But a prohibition imposed on the exercise of a fundamental right to carry on an occupation, trade or business will not be regarded as reasonable, if it is imposed not in the interest of the general public, but merely to respect the susceptibilities and sentiments of a section of the people whose way of life, belief or thought is not the same as that of the claimant".

The Supreme Court in the same case also held that [16]:

"Apparently another attempt, though on a restricted scale, to circumvent the judgment of this court in Mohammed Hanif Quareshi's case.... The effect of the impugned notification was to prohibit the slaughter of bulls and bullocks within the Municipality of Jabalpur, and the notification imposed a direct restriction upon the petitioners' rights under Article 19(1)(g)."

Over three decades later, the Supreme Court in the case of State of Gujarat vs Mirzapur Moti Kureshi Kaseab Jamat [17] discarded the balance and wiped out settled jurisprudence. On October 26, 2005, a seven member bench, constituted specially to overrule the judgment by a five-member Constitution Bench in Hanif Quareshi's case, upheld, by 6-1, a total ban on slaughter of cow. Speaking for the majority, Chief Justice R.C. Lahoti said [18]:

"Post Kesavananda Bharati[the Fundamental Rights case of 1973] so far as the determination of the position of Directive Principles, vis-a-vis Fundamental Rights are concerned, it has been an era of positivism and creativity. Article 37 of the Constitution while declaring the Directive Principles to be unenforceable by any court, goes on to say 'that they are nevertheless fundamental in the governance of the country'. The several clauses of Article 37 themselves need to be harmoniously construed assigning equal weightage to all of them. The end part of Article 37- 'it shall be the duty of the State to apply these principles in making laws' is not a pariah but a constitutional mandate. The series of decisions which we have referred to hereinabove and the series of decisions which formulate the three stages of development of the relationship between Directive Principles and Fundamental Rights undoubtedly hold that, while interpreting the interplay of rights and restrictions, Part III (Fundamental Rights) and Part IV (Directive Principles) have to be read together. The restriction which can be placed on the rights listed in Article 19(1) are not subject to Articles 19(2) to 19(6); the provisions contained in the chapter on Directive Principles of State Policy can also be pressed into service and relied on for the purpose of adjudging the reasonability of restrictions placed on the Fundamental Rights."

This turns Article 37 of Constitution of India on its head. The constitutionally prescribed restrictions on Fundamental Rights in Article 19(2) to (6) were of no moment. The Directive Principle Article 48 alone governed. Directive Principles are now to be used as an additional ground for restricting the Fundamental Rights in this judicially declared "era of positivism and creativity" which serves to help the court to accumulate power.

\section{In his dissenting, Justice A.K. Mathur said [19]:-}

"I do not think that it will be proper to reverse the view which has been held good for a long spell of time from 1958 to 1996. There is no material change in ground realities warranting reversal of earlier decisions.” The 1958 case was followed by the Supreme Court in 1961 and 1970. 
The Division Bench of the Supreme court on March 29, 2006, in Akhil Bharat Gosena Sangh vs State of A.P. \& Ors [20] the Supreme Court opined:

"The Constitution Bench of this Court in case held such a legislation to be constitutional in the light of the finding that the legislation was in furtherance of the directive in Article 48 of the Constitution and any enactment which furthers the cause in the Directive Principles of State Policy cannot be held to be unconstitutional"

The Supreme Court further noted that [21].

"It was, however, not held that permitting slaughter of bovine cattle by itself is unconstitutional".

\section{Personal Liberty and Right to Eat:-}

It is slaughter of cows that is banned, not consumption of beef. This brings us to the right to privacy and its corollary: the right to eat just what one chooses to eat. In two rulings the Supreme Court has held the right to eat to be a part of the fundamental right to "personal liberty" (Article 21). In Re Ramlila Maidan Incident [22] Justice B.S. Chauhan held that the:

"right of [sic] privacy and the right to sleep have always been treated to be a fundamental right like a right to breathe, to eat, to drink, to blink, etc.".

In Hinsa Virodhik Sangh vs Mirzapur Moti Kuresh Jamat [23] the Supreme Court said:

"A large number of people are non-vegetarian and they cannot be compelled to become vegetarian for a long period. What one eats is one's personal affair and it is a part of his right to privacy which is included in Article 21 of our Constitution as held by several decisions of this court"

Relying on decision of the Apex Court in the case of Kharak Singh v. State of Uttar Pradesh [24], the Bombay High Cour in a recent judgment in 06.05.2016 Shaikh Zahid Mukhtar and Ors. vs. The State of Maharashtra and Ors. held [25]:

"Article 21 includes the right to lead a meaningful life. It protects the citizen from unnecessary state intrusion into his home. For leading a meaningful life, a citizen will have to eat food and preferably food of his choice. If the state tells him not to eat a particular kind of food though the same is not injurious to health, it will prevent the citizen from leading a meaningful life. If the state starts making intrusion into the personal life of an individual by preventing him from eating food of his choice, such act may well affect his personal liberty. Hence, even assuming that there may not be any right of privacy, such interference will be violation of personal liberty guaranteed by the state."

The Shaikh Zahid Mukhtar and Ors. vs. The State of Maharashtra and Ors.[26] was a case that concerned the law enacted by the Maharashtra Assembly Bombay Animal Preservation Act, 1954 of Section 5A(1) of the Amendment Act of Maharashtra bans transport of cows outside the State for slaughter. Subsection (2) also bans their export outside for slaughter. The net result is (1) Slaughter of cows, bulls, etc. within Maharashtra is banned (2) Banned also is possession of their flesh provided that the person knew that it had been slaughtered within the State (3) But possession of the flesh of any cow, bull or bullock slaughtered outside Maharashtra is permitted and (4) The provision which throws the onus of proof on the accused is declared unconstitutional.

The result of this decision that the meat of cows, bulls or bullock slaughtered outside Maharashtra in any other State or, for that matter, in a foreign country, can lawfully be imported into Maharashtra for consumption by persons residing in the State. The two judges did not go further. They were bound by the judgment of a seven-member constitutional bench of State of Gujarat vs Mirzapur Moti Kureshi Kaseab Jamat [27] the Supreme Court in 2005.

\section{Conclusions:-}

India is a diverse nation as it possesses diversity in cultures, traditions and cuisines. The staple food of people of India varies from state to state. By the judgment of State of Gujarat vs Mirzapur Moti Kureshi Kaseab Jamat (2005), the seven judges' bench held the judgment of a total ban on slaughter of cow. Since this historic judgment [which overruled the judgment of Hanif Quereshi (1958)] all the High Courts and Supreme Courts have followed this judgment continuously as of 2017.

The point of concern is that there is a complete ban on cow slaughter and not on the consumption of beef and the present Modi Government is also following the same line of action in Courts and Administration. Also, the state legislatures of West Bengal, Kerala and the North-Eastern States (Seven sisters except Assam) haven't made any 
law in relation to cow slaughter. Thus, it is clear that these States do not have the same notion against cow slaughter like the rest of the country.

It will be seen that there is a complete lack of uniformity in the State laws. By and large, most of the laws prohibit the slaughter of cows of all ages although there are different laws in some other states. Therefore, it is necessary that an amendment in the constitution is made which ensures that 'preservation, protection and improvement of stock and prevention of animal diseases' is presently an item at Entry No. 15 of List II (State List) of the Constitution's Schedule VII. It may be transferred and put in list III (Concurrent List) so that the Parliament attains competence to make laws for the whole nation. Furthermore, the Central, after the proposed amendment, must make a rational law which concerns the whole nation in relation to cow slaughter. After the amendment, the Union Government should make laws in accordance to the eating habits of the people in the different parts of the country such as the states of North-East, Kerala and West Bengal. In other states where cow slaughter is considered an injury to the religious beliefs of the people and where cows are held sacred, slaughtering, of cows, consumption of beef and illegal smuggling of beef from other states must be banned completely. Similarly, in states where beef is a part of the staple diet (the North-East, West Bengal and Kerala) and the eating habits of the people adhere to consumption of beef and other animals' flesh, cow slaughter must be considered as a legal practice.

\section{References:-}

1. http://www.news18.com/news/business/economic-survey-2015-16-india-ranks-first-in-milk-productionaccounting-for-18-5-per-cent-of-world-production-1208209.html retrieved on 18 January 2017.

2. Government of India, Department of Animal Husbandry, Dairying \& Fisheries, ANNUAL REPORT - 2013-14

3. Constituent Assembly Debates, vol. VII, 19-11-1948

4. Constitution of India, Article 48

5. Constitution of India, Article 37

6. M.P. Jain, Indian Constitutional Law (Fifth ed. LexisNexis, Reprint 2009) p. 1363; see also Paschim Banga Khet Mazdoor Samity v State of West Bengal, (1996) 4 SCC 37: AIR 1996 SC 2426.

7. AIR 1981 SC 873

8. National Commission on Cattle report 2002, http://dahd.nic.in/documents/reports/report-national-commissioncattle Retrived on 26 December 2016.

9. (2005) 8 SCC 534

10. AIR 1958 SC 713

11. 11 ibid

12. ibid

13. AIR 1961 SC 448

14. ibid

15. AIR 1970 SC 96

16. ibid

17. Supra no. 9

18. ibid

19. ibid

20. 2006) 4 SCC 162.

21. ibid at 204

22. 2012) 5 SCC 1 and 121

23. 2005) 5 SCC 47

24. MANU/SC/0085/1962: (1964)1 SCR 332

25. MANU/MH/0670/2016 Para 193

26. MANU/MH/0670/2016

27. Supra no. 9 